Improvised Music after 1950: Afrological and Eurological Perspectives Author(s): George E. Lewis

Source: Black Music Research Journal, Vol. 16, No. 1, (Spring, 1996), pp. 91-122

Published by: Center for Black Music Research - Columbia College Chicago and University of Illinois Press

Stable URL: http://www.jstor.org/stable/779379

Accessed: 23/07/2008 16:49

Your use of the JSTOR archive indicates your acceptance of JSTOR's Terms and Conditions of Use, available at http://www.jstor.org/page/info/about/policies/terms.jsp. JSTOR's Terms and Conditions of Use provides, in part, that unless you have obtained prior permission, you may not download an entire issue of a journal or multiple copies of articles, and you may use content in the JSTOR archive only for your personal, non-commercial use.

Please contact the publisher regarding any further use of this work. Publisher contact information may be obtained at http://www.jstor.org/action/showPublisher?publisherCode=cbmr.

Each copy of any part of a JSTOR transmission must contain the same copyright notice that appears on the screen or printed page of such transmission.

JSTOR is a not-for-profit organization founded in 1995 to build trusted digital archives for scholarship. We work with the scholarly community to preserve their work and the materials they rely upon, and to build a common research platform that promotes the discovery and use of these resources. For more information about JSTOR, please contact support@jstor.org. 


\title{
IMPROVISED MUSIC AFTER 1950: AFROLOGICAL AND EUROLOGICAL PERSPECTIVES
}

\author{
GEORGE E. LEWIS
}

Since the early 1950 s controversy over the nature and function of improvisation in musical expression has occupied considerable attention among improvisers, composers, performers, and theorists active in that sociomusical art world that has constructed itself in terms of an assumed high-culture bond between selected sectors of the European and American musical landscapes. Prior to 1950 the work of many composers operating in this art world tended to be completely notated, using a wellknown, European-derived system. After 1950 composers began to experiment with open forms and with more personally expressive systems of notation. Moreover, these composers began to designate salient aspects of a composition as performer-supplied rather than composerspecified, thereby renewing an interest in the generation of musical structure in real time as a formal aspect of a composed work.

After a gap of nearly one hundred and fifty years, during which realtime generation of musical structure had been nearly eliminated from the musical activity of this Western or "pan-European" tradition, the postwar putative heirs to this tradition have promulgated renewed investigation of real-time forms of musicality, including a direct confrontation with the role of improvisation. This ongoing reappraisal of improvisation may be due in no small measure to musical and social events taking place in quite a different sector of the overall musical landscape. In particular, the anointing, since the early 1950s, of various forms of "jazz," the AfricanAmerican musical constellation most commonly associated with the ex-

GEORGE E. LEWIS, Professor of Music in the Critical Studies/Experimental Practices program at the University of California, San Diego, is an improviser-trombonist, composer, performer, and computer-installation artist. Lewis is a 25-year member of the Association for the Advancement of Creative Musicians. He has presented his interdisciplinary compositions in many countries around the world and on more than ninety sound recordings. 
ploration of improvisation in both Europe and America, as a form of "art" has in all likelihood been a salient stimulating factor in this reevaluation of the possibilities of improvisation.

Already active in the 1940s, a group of radical young black American improvisers, for the most part lacking access to economic and political resources often taken for granted in high-culture musical circles, nonetheless posed potent challenges to Western notions of structure, form, communication, and expression. These improvisers, while cognizant of Western musical tradition, located and centered their modes of musical expression within a stream emanating largely from African and AfricanAmerican cultural and social history. The international influence and dissemination of their music, dubbed "bebop," as well as the strong influences coming from later forms of "jazz," has resulted in the emergence of new sites for transnational, transcultural improvisative musical activity.

In particular, a strong circumstantial case can be made for the proposition that the emergence of these new, vigorous, and highly influential improvisative forms provided an impetus for musical workers in other traditions, particularly European and American composers active in the construction of a transnational European-based tradition, to come to grips with some of the implications of musical improvisation. This confrontation, however, took place amid an ongoing narrative of dismissal, on the part of many of these composers, of the tenets of African-American improvisative forms.

Moreover, texts documenting the musical products of the American version of the move to incorporate real-time music-making into composition often present this activity as a part of "American music since 1945," a construct almost invariably theorized as emanating almost exclusively from a generally venerated stream of European cultural, social, and intellectual history-the "Western tradition." In such texts, an attempted erasure or denial of the impact of African-American forms on the realtime work of European and Euro-American composers is commonly asserted.

This denial itself, however, drew the outlines of a space where improvisation as a theoretical construct could clearly be viewed as a site not only for music-theoretical contention but for social and cultural competition between musicians representing improvisative and compositional modes of musical discourse. The theoretical and practical positions taken with regard to improvisation in this post-1950 Euro-American tradition exhibit broad areas of both confluence and contrast with those emerging from musical art worlds strongly influenced by African-American improvisative musics.

This essay attempts to historically and philosophically deconstruct as- 
pects of the musical belief systems that ground African-American and European (including European-American) real-time music-making, analyzing the articulation and resolution of both musical and what were once called "extramusical" issues. This analysis adopts as critical tools two complementary connotative adjectives, "Afrological" and "Eurological." These terms refer metaphorically to musical belief systems and behavior which, in my view, exemplify particular kinds of musical "logic." At the same time, these terms are intended to historicize the particularity of perspective characteristic of two systems that have evolved in such divergent cultural environments.

Improvisative musical utterance, like any music, may be interpreted with reference to historical and cultural contexts. The history of sanctions, segregation, and slavery, imposed upon African Americans by the dominant white American culture, has undoubtedly influenced the evolution of a sociomusical belief system that differs in critical respects from that which has emerged from the dominant culture itself. Commentary on improvisation since 1950 has often centered around several key issues, the articulation of which differs markedly according to the cultural background of the commentators-even when two informants, each grounded in a different system of belief, are ostensibly discussing the same music.

Thus, my construction of "Afrological" and "Eurological" systems of improvisative musicality refers to social and cultural location and is theorized here as historically emergent rather than ethnically essential, thereby accounting for the reality of transcultural and transracial communication among improvisers. For example, African-American music, like any music, can be performed by a person of any "race" without losing its character as historically Afrological, just as a performance of Karnatic vocal music by Terry Riley does not transform the raga into a Eurological music form. My constructions make no attempt to delineate ethnicity or race, although they are designed to ensure that the reality of the ethnic or racial component of a historically emergent sociomusical group must be faced squarely and honestly.

In developing a hermeneutics of improvisative music, the study of two major American postwar real-time traditions is key. These traditions are exemplified by the two towering figures of 1950s American experimental musics-Charlie "Bird" Parker and John Cage. The work of these two crucially important music-makers has had important implications not only within their respective traditions but intertraditionally as well. The compositions of both artists are widely influential, but I would submit 
that it is their real-time work that has had the widest impact upon world musical culture. The musics made by these two artists, and by their successors, may be seen as exemplifying two very different conceptions of real-time music-making. These differences encompass not only music but areas once thought of as "extra-musical," including race and ethnicity, class, and social and political philosophy.

\section{Bird}

In the musical domain, improvisation is neither a style of music nor a body of musical techniques. Structure, meaning, and context in musical improvisation arise from the domain-specific analysis, generation, manipulation, and transformation of sonic symbols. Jazz, a largely improvisative musical form, has long been explicitly and fundamentally concerned with these and other structural issues. For African-American improvisers, however, sonic symbolism is often constructed with a view toward social instrumentality as well as form. New improvisative and compositional styles are often identified with ideals of race advancement and, more importantly, as resistive ripostes to perceived opposition to black social expression and economic advancement by the dominant white American culture.

Ebullient, incisive, and transgressive, the so-called "bebop" movement brought this theme of resistance to international attention. Influencing musicality worldwide, the movement posed both implicit and explicit challenges to Western notions of structure, form, and expression. In the United States, the challenge of bop, as exemplified by the work of Charlie "Bird" Parker, Dizzy Gillespie, Thelonious Monk, Bud Powell, and Kenny "Klook" Clarke, obliged the dominant European-American culture to come to grips, if not to terms, with Afrological aesthetics.

Bop improvisers, like earlier generations of jazz improvisers, used "heads," or precomposed melodic material, as starting points for a piece. Bop heads, however, as Gridley $(1994,165)$ points out, "resembled little or nothing that the average listener had heard before." In a further abstraction, bebop improvisers felt no obligation to use the melodic material of the "head" as material for improvisational transformation. Instead, the underlying harmonic sequence, usually subjected to extensive reworking by the improvisers, became the basis for improvisation. Often this harmonic material was appropriated from the popular show tunes of the day, linking this music with earlier jazz styles. The musicians often "signified on" the tunes, replacing the melodic line with another, then naming the new piece in an ironic signifying riff on Tin Pan Alley as well as upon the dominant culture that produced it. 
Bebop raised the stakes in the game of cultural thrust and parry to a new level of intensity, providing models of both individual and collective creativity that were adopted and extended during later periods in improvised music. The outlines of this model are well described by Walton $(1972,95)$, who characterizes bebop as requiring "concentrated listening, allowing an expansion of self through identification with the symbolic communication of the performer." Moreover, through extensive improvisation, each performance of a given bebop "piece" could become unique, different in many respects from the last. Even in many strains of Afrological improvisative practice today, the generative and interactional aspects of how the roles of both improviser and listener are constructed carries distinct traces of the attitudes promulgated by bebop improvisers.

Bebop's challenge to the dominant culture was not limited to musical concerns; in fact, bebop musicians challenged traditional notions of intraand extra-musicality. The composer and improviser Anthony Braxton $(1985,124)$ comments that "bebop had to do with understanding the realness of black people's actual position in America." Frank Kofsky (1970, 270-271) quotes Langston Hughes's blues signifyin' on bebop's origins in "the police beating Negroes' heads ... that old club says, 'BOP! BOP! ... BE-BOP! ... That's where Be-Bop came from, beaten right out of some Negro's head into them horns."

In Blues People, Amiri Baraka (then LeRoi Jones) asserts that bebop "had more than an accidental implication of social upheaval associated with it" (Jones 1963, 188). For the bebop musicians this upheaval had a great deal to do with the assertion of self-determination with regard to their role as musical artists. While jazz has always existed in the interstices between Western definitions of concert music and entertainment, between the commercial and the experimental, challenging the assigned role of the jazz musician as entertainer created new possibilities for the construction of an African-American improvisative musicality that could define itself as explicitly experimental.

This radical redefinition was viewed as a direct challenge, by extension, to the entire social order as it applied to blacks in 1940s apartheid America: "The young Negro musician of the forties began to realize that merely by being a Negro in America, one was a nonconformist" (Jones $1963,188)$. Indeed, the musicians were often called "crazy" - an appellation often assigned to oppositional forces, either by the dominant order itself or by members of an oppressed group who, however onerous their present situation, are fearful of the consequences of change. 


\section{Cage}

In his essay exploring improvisation, the theorist Carl Dahlhaus provides us with five defining characteristics of a musical work that, in his view, must be present for the work to be considered a composition. These characteristics are interconnected in a kind of logically daisy-chained sentence, which I will present in exploded form.

According to Dahlhaus, a composition is, first, an individually complete structure in itself ("ein in sich geschlossenes, individuelles Gebilde"). Second, this structure must be fully worked-out ("ausgearbeitet"). Third and fourth, it is fixed in written form ("schriftlich fixiert") in order to be performed ("um aufgeführt zu werden"). Finally, what is worked-out and notated must constitute the essential part of the aesthetic object that is constituted in the consciousness of the listener ${ }^{1}$ (Dahlhaus $1979,10-11)$.

That these five characteristics identify the very notion of composition as European in nature is asserted by Dahlhaus at several points. The dialectic between composition and notation, according to Dahlhaus, is critical to the notion of composition itself. Compositions that are worked-out without being notated, in Dahlhaus's view, are neither compositions nor improvisations (21). Dahlhaus, however, does not present his own view about just what such a hybrid might be called or how, given his definitional stance, the nature of such music might be accounted for theoretically.

Recognizing that his definition excludes much non-European music, Dahlhaus consoles the reader with the thought that some things simply are what they are: "A historian who hesitates to describe a piece of nonEuropean music as composition gives, by so doing, no understanding that he values it any the less"2 (22). In any event, given the explicitly particularist nature of Dahlhaus's theory, characterizing it as prototypically Eurological should present no great analytical obstacles.

The work of John Cage presents an explicit challenge to this fixed notion of composition. Like Bird, the activity of Cage and his associates, such as Christian Wolff, David Tudor, Morton Feldman, and Earle Brown, had profound and wide-ranging influence not only in the musical, literary, and visual domains but socially and culturally as well. The musical and theoretical work of these composers can be credited with radically reconstructing Eurological composition; the trenchancy of this reconstruction involved in large measure the resurrection of Eurological modes of

1. Das Ausgearbeitete und Notierte den essentiellen Teil des ästhetischen Gegenstandes ausmacht, der sich im Bewußtsein des Hörers konstituiert.

2. Ein Historiker, der zögert, ein Stück außereuropäische Musik als Komposition zu bezeichnen, gibt dadurch keineswegs zu erkennen, daß er es gering schätzt. 
real-time musical discourse, often approaching an explicitly improvisative sensibility.

Along with his associates, Cage was responsible for the entrance into musical history of the term "indeterminacy." Cage's essay on indeterminacy from Silence (Cage 1961, 35-40) presents examples of "indeterminate" elements in European music from the last two centuries, from Karlheinz Stockhausen's Klavierstück XI to J. S. Bach's Art of the Fugue. According to Cage, Bach's non-specification of timbre and amplitude characteristics identifies these elements not as absent but simply as nondetermined but necessary material, to be realized by a performer. The construction as indeterminate of non-specified elements in the Bach work allows "the possibility of a unique overtone structure and decibel range for each performance" (35). The performer's function in this case is "comparable to that of someone filling in color where outlines are given" (35).

Later descriptions of indeterminacy, such as that advanced by Elliott Schwartz and Daniel Godfrey (1993) in their survey text on "music since 1945," define a musical factor as indeterminate "if it is dictated by chance and operates without any links to other factors" (92). Cage's own initial definition of indeterminacy, however, did not necessarily include the use of chance as a salient factor. In Silence, Cage $(1961,35)$ provides several methods, unranked as to preference, by which the performer may realize the indeterminate aspects of the Art of the Fugue: "feeling his way, following the dictates of his ego ... following his taste ... employing some operation exterior to his mind: tables of random numbers ... or chance operations, identifying there with no matter what eventuality."

Another of Cage's lasting contributions to both compositional and improvisative method is the radical use of these "chance operations." The 1951 Music of Changes was composed by Cage using the ancient Chinese oracular method known as the IChing, or Book of Changes, to generate musical material within parameters chosen by the composer. The object of the use of the I Ching, as described by the composer himself in explaining his compositional process for the Music of Changes, is the creation of "a musical composition the continuity of which is free of individual taste and memory (psychology) and also of the literature and 'traditions' of the art" (Cage 1961, 59). In this regard, Cage consistently maintains that "sounds are to come into their own, rather than being exploited to express sentiments or ideas of order" (69).

Cage, though perhaps not the first to promulgate the concept of the experimental in music, did provide, in his important manifesto, Silence, several working definitions for the term "experimental music." The composer has written that "an experimental action is one the outcome of which is not foreseen" and is "necessarily unique" (39). Cage's notion of 
spontaneity and uniqueness was informed by his studies of Zen and in particular by his attendance at Daisetz Suzuki's early 1950s lectures on that subject in New York City (Revill 1992, 108-110).

That this view of music would have social implications was fully recognized by Cage himself. Indeed, Cage's social and philosophical views form a prominent part of the literature about him. In the Kostelanetz interviews from 1987, Cage explicitly addresses his own essential anarchism at several points (Kostelanetz 1987, 266). Connecting his view of sound to his anarchism, the composer expresses his need for "a music in which not only are sounds just sounds but in which people are just people, not subject, that is, to laws established by any one of them, even if he is 'the composer' or 'the conductor.' . . . Freedom of movement is basic to both this art and this society" (257).

Cage's notion of social instrumentality, however, does not connect this very American notion of freedom-perhaps reminiscent of the frontier myth - to any kind of struggle that might be required in order to obtain it. The composer denies the utility of protest, maintaining that "my notion of how to proceed in a society to bring change is not to protest the thing that is evil, but rather to let it die its own death. ... Protests about these things, contrary to what has been said, will give it the kind of life that a fire is given when you fan it, and that it would be best to ignore it, put your attention elsewhere, take actions of another kind of positive nature" (Kostelanetz 1987, 265-266).

In terms of social location, composers such as Cage and Feldman located their work as an integral part of a sociomusical art world that explicitly bonded with the intellectual and musical traditions of Europe. The members of this art world, while critiquing aspects of contemporary European culture, were explicitly concerned with continuing to develop this "Western" tradition on the American continent. The composer's "History of Experimental Music in the United States" (Cage 1961, 67-75) identifies as relevant to his concerns both European and American composers and artists, including the European Dada movement, composers such as Debussy and Varèse, and later European experimentalists such as Pierre Boulez, Karlheinz Stockhausen, Luigi Nono, and Luciano Berio. Among the American composers that Cage mentions as being part of America's "rich history" of music are Leo Ornstein, Dane Rudhyar, Lou Harrison, Harry Partch, and Virgil Thomson.

Though these and other composers do earn criticism, the only indigenous music that receives sharp denunciation from Cage is the AfricanAmerican music that he frequently refers to as "hot jazz." Criticizing the expression of Henry Cowell's interest in this and other American indigenous traditions, Cage appropriates the then-current conventional wis- 
dom about the opposition between "jazz" music and "serious" music: "Jazz per se derives from serious music. And when serious music derives from it, the situation becomes rather silly" (Cage 1961, 72).

We may regard as more rhetorical device than historical fact Cage's brief account of the origins of jazz. In any event, despite such declarations as "the world is one world now" (Cage 1961, 75) or "when I think of a good future it certainly has music in it but it doesn't have one kind ... it has all kinds" (Kostelanetz 1987, 257), it is clear that Cage has drawn very specific boundaries, not only as to which musics are relevant to his own musicality but as to which musics suit his own taste. The Cageian tendency is to confront this contradiction through the use of terms that essentially exnominate or disguise his likes and dislikes as such: "some music ... which would not be useful to me at all might be very useful to someone else" (Kostelanetz 1987, 257).

The composer does, however, make allowance for the fact that others may draw different boundaries: "I can get along perfectly well without any jazz at all; and yet I notice that many, many people have a great need for it. Who am I to say that their need is pointless?" (Kostelanetz 1987, 257). This basic reference to freedom of choice, however, can hardly be extrapolated to argue that Cage is characterizing himself as possessing a culturally diverse musical sensibility. Rather, the composer is reaffirming a relatively mundane truism concerning the diversity of personal taste, while simultaneously making clear that, for him, a "need for jazz" would indeed be pointless.

\section{Exnomination}

Despite Cage's disavowal of jazz, however, the historical timeline shows that Cage's radical emphasis upon spontaneity and uniquenessnot generally found in either American or European music before Cagearrives some eight to ten years after the innovations of bebop. And it is certain that bebop, a native American music with a strong base in New York City, was well known to what has come to be known as the "New York School" of artists and musicians of which Cage and Feldman were part. In the case of visual artists from that social circle, such as Jackson Pollock and Franz Kline, the connection with jazz has been remarked upon in a number of essays (see Mandeles 1981, 139).

The composer Anthony Braxton's pithy statement concerning the disavowal of Afrological forms by the art world that nurtured Cage's work advances the essential issue directly: "Both aleatory and indeterminism are words which have been coined ... to bypass the word improvisation and as such the influence of non-white sensibility" (Braxton 1985, 366). 
Why improvisation and non-white sensibility would be perceived by anyone as objects to be avoided can usefully be theorized with respect to racialized power relations.

Commentators such as the media critic John Fiske, the cultural theorist George Lipsitz, and the legal scholar Cheryl I. Harris have identified "whiteness" as an important cultural construct in American society. For Harris and Lipsitz, whiteness is a historically emergent phenomenon; for Lipsitz, whiteness appears in large measure "because of realities created by slavery and segregation, immigration restriction and Indian policy, by conquest and colonialism" (Lipsitz 1995, 370).

Both Lipsitz and Harris have recourse to economic terms in describing the role of whiteness. Harris traces the evolution of the construction of whiteness as a form of legally constituted property, while Lipsitz refers to a "possessive investment in whiteness." Quoting legal theorist Kimberlé Crenshaw, Harris $(1993,1759)$ utilizes the language of investment in referring to the "actual stake in racism" that the previously Balkanized European ethnics developed, through the legal and social privileges that attend their classification as "white."

For Fiske, whiteness is "not an essential racial category that contains a set of fixed meanings, but a strategic deployment of power... The space of whiteness contains a limited but varied set of normalizing positions from which that which is not white can be made into the abnormal; by such means whiteness constitutes itself as a universal set of norms by which to make sense of the world" (Fiske 1994, 42). Fiske identifies "exnomination" as a primary characteristic of whiteness as power: "Exnomination is the means by which whiteness avoids being named and thus keeps itself out of the field of interrogation and therefore off the agenda for change. ... One practice of exnomination is the avoidance of self-recognition and self-definition. Defining, for whites, is a process that is always directed outward upon multiple 'others' but never inward upon the definer" (42).

It is my contention that, circumstantially at least, bebop's combination of spontaneity, structural radicalism, and uniqueness, antedating by several years the reappearance of improvisation in Eurological music, posed a challenge to that music which needed to be answered in some way. All too often, the space of whiteness provided a convenient platform for a racialized denial of the trenchancy of this challenge, while providing an arena for the articulation of an implicit sensibility which I have termed "Eurological."

The anthropologist and improviser Georgina Born presents the circumstantial case: 
Some of the main elements of experimental music practice-improvisation, live group work, the empirical use of small, commercial electronics in performance-were pioneered in the jazz and rock of the 1950s and 1960s. Moreover, the politics of experimental music are similar to those of the advanced black jazz of the ' 60 s. Its musical collectivism, for example, was prefigured by the Chicago black musicians' cooperative, the Association for the Advancement of Creative Musicians (AACM), which became a model for later progressive, cooperative music organizations. The fact that these influences often remain unacknowledged and subterranean, even within experimental music, signals their status as deriving from an "other" culture and the reluctance of the postmodern sphere of legitimate music to admit its indebtedness to the "other." (Born 1995, 351, n29)

The sociologist Howard Becker, using an example from jazz, identifies an explicit aesthetic system as being useful to an art world by conditioning competition and justifying access to resources:

It ties participants' activities to the tradition of the art, justifying their demands for the resources and advantages ordinarily available to people who produce that kind of art. To be specific, if I can argue cogently that jazz merits as serious consideration on aesthetic grounds as other forms of art music, then I can compete, as a jazz player, for grants and fellowships from the $\mathrm{Na}$ tional Endowment for the Arts and faculty positions in music schools, perform in the same halls as symphony orchestras, and require the same attention to the nuances of my work as the most serious classical composer. (Becker 1982, 132-133)

In a transnational, transcultural musical environment where exchanges of musical information are increasingly commonplace, ethnicized or racialized grounds for classification of musical discourse, though not explicitly named, nevertheless become disclosed. Advocates of particular aesthetic systems are rarely as explicit as Becker would have it about class and race grounding, often preferring to couch support of certain musical forms and disavowal of others in "objective" terms. Despite Baraka's contention that bebop was the African-American musical form that obliged the larger society to confront Afrological aesthetics in creative black music itself as "art" (Jones 1963, 190), the fact that both Bird and Cage expressed an experimental bent in describing their respective creative processes has not, so far, induced the authors of music history texts concerned with "American music since 1945" to classify the output of these two composers according to their relationship with the experimental.

Instead, texts appropriating the term "experimental music" construct this classification as denoting a particular group of postwar music-makers who come almost exclusively from either European or EuropeanAmerican heritage. Michael Nyman's important book Experimental Music 
(1974) is representative. This text, like most others, presents this group of composers as the intellectual heirs to what is vernacularly known as the "classical" or "Western" tradition, even when this tradition is subjected to critique through its inheritors' music.

Coded qualifiers to the word "music"-such as "experimental," "new," "art," "concert," "serious," "avant-garde," and "contemporary"-are used in these texts to delineate a racialized location of this tradition within the space of whiteness; either erasure or (brief) inclusion of Afrological music can then be framed as responsible chronicling and "objective" taxonomy. The passing reference to the Art Ensemble of Chicago in the Schwartz and Godfrey text on Music Since 1945, for example, was necessary "because their music was as much 'serious' or avant-garde music as jazz" (Schwartz and Godfrey 1993, 202). The quote demonstrates the role assumed by whiteness in defining the Art Ensemble as not quite so "other" as some of the others.

The improviser-theorists Malcolm Goldstein (1988) and Derek Bailey (1992) both discuss the decline and eventual near-disappearance in the nineteenth century of improvisative development in European music. Both authors refer to a gap of about 150 years in the European intellectual history of improvisation, from the late eighteenth to the mid-twentieth century. As with a number of texts dealing with Eurological improvised music, however, the composer and theorist David Cope feels obliged to mention that despite an apparent gap in the improvisational record, improvisation has indeed been part of European musical history.

In particular, two long-dead musical practices, the use of figured bass and the performance of cadenzas, are invoked by Cope $(1993,127)$ to assure the reader that improvisation indeed has a long tradition in European music. The third major stream within European improvisation, the small yet persistent French school of organ improvisers, is not mentioned in the Cope text. Bailey $(1992,29)$, writing about improvisation in various world musical traditions, identifies this group as representing practically the only improvisative activity in European music from the end of the eighteenth century to the mid-twentieth.

In any event, survivals or retentions of improvisative traditions in present-day Eurological improvisation have only begun to be identified and researched. Information about those survivals that have been found would, so far, appear insufficiently well-documented or disseminated to provide a historical or cultural basis for the reemergence of improvisation in Eurological music in the mid-1950s. In this light, Cope's cautious claim that "the circumstances under which more recent improvisation developed are less clear. ... Interest in this century may be rooted in jazz" (127) may be viewed as an excellent illustration of Born's remark about the re- 
luctance of commentators on Eurological music to admit indebtedness to "the other."

Exemplifying the sort of exnomination of whiteness that Fiske and Born identify, the Cope text rigorously avoids extended, serious treatment of major figures in postwar Afrological improvisation, while devoting considerable attention to something called "contemporary" improvisation. Improvisers of worldwide stature-such as Parker, Coltrane, Taylor, and Coleman - are (at best) mentioned in passing, while pages are devoted to the work of relatively obscure individuals whose written descriptions of their improvisations far outpace in quantity their audio documentation.

The reader is encouraged to assume that this kind of "contemporary" improvisation, despite the fact that a number of its proponents "are or were actively involved in jazz" (Cope 1993, 127), must have developed sui generis-perhaps in a sort of immaculate conception. According to Cope, the likeliest origin of this sort of improvisation lay, not in any kind of musical miscegenation with jazz, but in "classical" performers" "inability to realize correctly the complexities of recent music; the composer, perhaps out of frustration, perhaps because the result was the same or better, chose to allow a certain freedom in performance" (127).

\section{Jazz as Epistemological Other}

Eurological modernist music criticism, while erasing the practitioners of Afrological improvised music from postwar histories of "contemporary" music, has nonetheless felt obliged to present a series of ongoing critiques of its construction of "jazz." Such critiques may represent an attempt to create what social scientists Somers and Gibson term an "epistemological other." According to Somers and Gibson (1994, 38), social groups often perform such constructions "to consolidate a cohesive selfidentity and collective project."

The construction of the epistemological other may be viewed as the contrapositive aspect of the construction of whiteness, particularly when coded appeals to racial and ethnic solidarity are involved. John Cage's critique of jazz-well presented in his 1966 interview with the jazz critic Michael Zwerin-is of relatively little value as music criticism but may serve us well here as a textbook example of the power relationships that Fiske has recognized. In response to Zwerin's query about his thoughts on jazz, Cage replies, "I don't think about jazz, but I love to talk, so by all means, come on up" (Zwerin 1991, 161).

To this African-American observer, situated in the 1990s, the interview should perhaps have ended there. From a 1960s perspective, however, we 
are in the presence of power, as two white males prepare to discuss "the trouble with black people" without, in the declining days of American high media apartheid, having to worry about a response. Even on a subject to which he freely admitted his lack of attention, Cage's opinion was apparently deemed sufficiently authoritative, by the structures of media power that decide such things, for the interview to continue and, finally, to be published and reprinted.

The colloquy between Cage and Zwerin, like Schwartz and Godfrey's reference to the Art Ensemble, displays whiteness in its defining role. Zwerin, though supposedly taking the side of jazz, ends up agreeing with Cage that jazz could use some work. The work of black artists is defined by whiteness as the primitive (yet improving) work of children: "But jazz is still young, and still evolving"; jazz could benefit from serious study of "our" models; already, it has started to explore areas "suggested by Ives"; "jazz is getting freer" through the use of tone-rows, and "getting away from the time dependence-inferring it rather than clobbering you with it all the time"; and so on (162-164).

In this wide-ranging, blunderbuss attack on black musical culture, both the assignment by Zwerin to Cage of the role of aesthetic arbiter and the acceptance and performance of this role by Cage serve to present whiteness as a normalizing position from which others are judged. At the same time, the "arguments" presented by both men against Afrological forms are framed in ostensibly "objective" musical terms, thereby exnominating their basis in notions of whiteness. Moreover, the process of erasure or gatekeeping with regard to media access by alternative voices-particularly black voices-ensured that neither a more worthy adversary nor a more wide-ranging set of topics-such as a contrapositive critique of Eurological forms-would be presented. Witness Coltrane's laconic but pregnant comment to Kofsky concerning media criticism: "I don't make the phrases" (quoted in Kofsky 1970, 225).

Clearly jazz must have been a powerful force in postwar improvisative music, since so many fledgling Eurological improvisers needed to distance themselves from it in one way or another. In this regard, the ongoing Eurological critique of jazz may be seen as part of a collective project of reconstruction of a Eurological real-time musical discipline. This reconstruction may well have required the creation of an "other"-through reaction, however negative, to existing models of improvisative musicality.

Indeed, the avoidance of jazz, and its recasting in the form of an epistemological other, has served explicitly as a defining pattern that served to animate many projects in the formation and exploration of a particularly Eurological improvisative sensibility. For example, in 1955 the Eu- 
ropean composer Lukas Foss organized a group devoted to "nonjazz" group improvisation (Schwartz and Godfrey 1993, 63). In addition, a number of the early postwar European and Euro-American experimenters working in Eurological forms had, in fact, been jazz musicians. The British improvisers who formed the free improvisation group AMM describe in detail their need to break away from the "very emulative style of American jazz" that they had been performing (Childs and Hobbs 1982-83, 34). The American composer Larry Austin, relating his experiences with group improvisation in the early 1960s, describes his group as having "consciously ruled out any overt jazz expression" (quoted in Childs and Hobbs 1982-83, 30-31). Apparently, according to Austin's account, this attempt on the part of his improvising group to erase jazz from their bodies was not entirely successful; Foss still detected traces of jazz, or Afrological, sensibilities in the group's work.

Despite this rather powerful circumstantial evidence, however, most survey texts dealing with this period in Eurological music are unfailingly solicitous in disabusing the reader of any nascent notion that jazz could have had any impact on the development of either "contemporary" improvisation or indeterminacy. These texts, despite the apparent concern of their authors with creating separate tables at the restaurant for indeterminacy and improvisation, nonetheless typically discuss both of these musical activities in the same chapter-thus effectively associating them.

Paul Berliner's encyclopedic study of the creative process among jazz musicians discusses the use of harmonic sequences or "progressions" as a basis for improvisation. The author asserts that improvisers liken a harmonic sequence or "progression" to "a road map for charting the precise melodic course of a rendition" (Berliner 1994, 71) - remarkably similar to Cage's already cited notion of a performer's function with regard to indeterminate scores as "filling in color where outlines are given." Thus, a strong case could be made for the contention that, just as chance operations can constitute one method for realizing performer indeterminacy, performer indeterminacy may be one method of realizing an improvisation. On this view, despite Cope's cautious statement that "one major precursor of musical indeterminacy may be improvisation" (Cope 1993, 124), indeterminacy could well be not a successor to improvisation but a subset of it.

\section{Spontaneity}

Spontaneity is an important value for improvisers working in both Eurological and Afrological forms, though the definition of spontaneity certainly differs according to tradition. Following Cage, Schwartz and God- 
frey $(1993,92)$ affirm that the result of a musical experience created through indeterminate means is meant to be "immediate, spontaneous, and unique: a ritual celebration, not a fixed art object bounded by predetermined relationships or notational straitjackets."

Notions of uniqueness and the unforeseen, however, are hardly unique to Eurological indeterminacy. Saxophonist Steve Lacy observed that "you have all your years of preparation and all your sensibilities and your prepared means but it is a leap into the unknown" (quoted in Bailey 1992, 57). Many commentators have identified the uniqueness of an improvisation as a highly prized goal among African-American improvisers. Berliner $(1994,268)$ quotes the trumpeter Doc Cheatham, whose work straddles the pre- and postwar eras, to the effect that Armstrong and others of comparable creative ability would "play fifteen or thirty different choruses, and they would never play the same thing. ... Every time they'd play a tune, the solo would be different." A similar sentiment was expressed with Coltrane's amazement at how Gillespie could play the introduction to "I Can't Get Started" differently every time (Berliner 1994, 269).

Despite the statements of these and other highly experienced improvisers who have gone on record with their experiences of uniqueness and discovery, a number of composers and theorists working in Eurological music have asserted a quite different view of the same music. The cognitive psychologist John Sloboda $(1985,141)$ maintains that jazz improvisers use "a model which is, in most cases, externally supplied by the culture." Lukas Foss has asserted that in improvisation, "one plays what one already knows" (quoted in Cope 1993, 127).

This viewpoint, which has attained the status of conventional wisdom in some circles, is similar to Schwartz and Godfrey's claim that "Cage's indeterminacy should be distinguished from improvisation, in that the latter is directed to a known end" (92). Cage's own statement that "improvisation is generally playing what you know" leads naturally to his opinion that improvisation "doesn't lead you into a new experience" (quoted in Kostelanetz 1987, 223).

The cognitive psychologist Philip Johnson-Laird has termed one version of this conventional wisdom as the "motif" theory. According to Johnson-Laird's construction of this theory, jazz improvisers are wont to use a set of memorized motifs, which are "strung together one after the other to form an improvisation" (Johnson-Laird 1991, 292). The scientist's own metaphor of improvisation, involving an approach to the analysis of bebop solos based in theories of generative grammars, likens improvisation to speech. This perceived similarity to speech leads Johnson-Laird to question the validity of the motif theory: "Discourse would be intolera- 
bly difficult if it consisted solely in stringing together remarks that one had committed to memory. It is this sort of stilted jumble of phrases that one is forced to produce in a foreign language where one's only guide is indeed a book of 'licks,' i.e., a phrase book" (293).

Johnson-Laird goes on to ask: "Why can we be confident that the 'motif' theory is wrong? . . First somebody has to invent the motifs. If a musician is the first to play a particular motif, then he or she cannot merely be regurgitating it from memory." Johnson-Laird adduces two other reasons for the doubtful validity of this theory: "an analysis of corpora of the musician's improvisation yields many phrases that occur only once. Third, the labour of committing to memory a sufficient number of motifs to guarantee the improvisation of complete solos is altogether too large to be practical" (293).

The motif theory, in both its scientific and its vernacular versions, denies the possibility of achieving creative agency and experiential spontaneity through improvisative musicality. For example, Dahlhaus (1979, 10), commenting on improvisation from the standpoint of a variant of this theory, finds a contradiction in the notion that an improvisation is "on the one hand pieced together from formulae and on the other hand experienced as spontaneous." ${ }^{3}$ The motif theory, with its overemphasis upon the role of memory in Afrological improvisation, has often been used by commentators, often influenced by the work of John Cage, to define improvisation in terms of a pure spontaneity, unmediated by memory. The composer and theorist Larry Solomon $(1985,226)$, for example, has defined the "fundamental ideal" of improvisation as "the discovery and invention of original music spontaneously, while performing it, without preconceived formulation, scoring, or content."

Buried within this Eurological definition of improvisation is a notion of spontaneity that excludes history or memory. In this regard, "real" improvisation is often described in terms of eliminating reference to "known" styles. Among the styles that are already "known," "jazz" is the most often cited in the literature on the subject-perhaps by reason of its role as epistemological other. According to composer Harold Budd, for instance, "Jazz, after all, has a noble tradition. Everybody knows what it is" (quoted in Childs and Hobbs 1982-83, 53). In posing the question about how far "originality" may be carried in creating "truly improvised" music, Solomon asks: "Would this also exclude reproducing a known style of music, such as jazz?" (226). The inescapable conclusion from a Eurological standpoint is that jazz, whose character is "known," cannot be truly spontaneous or original. Moreover, jazz's supposed de-

3. Daß sie einerseits aus Formeln zusammengestückt sei und andererseits als spontan empfunden werde. 
pendence upon memorized motifs prevents it from exemplifying "true" improvisation-despite its practitioners' experience of it.

Bailey $(1992, x i-x i i)$ theorizes about the interface with "known" styles in improvisation with his distinction between "idiomatic" and "nonidiomatic" forms of improvisation. This mode of theorizing, however, allows "true" improvisation to take place in both, while avoiding fixed definitions of spontaneity based on historical or cultural reference: "Idiomatic improvisation . . . is mainly concerned with the expression of an idiom-such as jazz, flamenco or baroque-and takes its identity and motivation from that idiom. Non-idiomatic improvisation has other concerns and is most usually found in so-called 'free' improvisation and, while it can be highly stylised, is not usually tied to representing an idiomatic identity."

From the Eurological perspective, allowing chance to enter the performance becomes an important method of avoiding "known" models of improvisation. Solomon $(1985,227)$ feels that improvisation "relies on the performer's control and intuition but also includes chance as a pathway to exploration and discovery." Schwartz and Godfrey $(1993,414)$ refer to "whims, wills-and accidents" as contributing to a sense of unpredictability. Berio $(1985,84)$ theorizes jazz improvisation as "a continuous correction of little errors, a continuous adjusting of sights relative to a target that, by its very nature, is never perfectly clear and defined."

As with any music, close listening and analysis of improvised music requires attention to information at different laminar depths. Thus, each of the numerous released recordings of, say, Coltrane's "Giant Steps," regarded at the level of individual passages, is the result of careful preparation-"ausgearbeitet." At the same time, each improvisation, taken as a whole, maintains its character as unique and spontaneous.

The Eurological notion of pure spontaneity in improvisation fails to account for this temporally multilaminar aspect of an improvisation. By fixing upon the surface level of immediate spontaneity, unsullied by reference to the past or foreshadowing of the future, the reduction of the notion of improvisative spontaneity to the present moment insists on ephemerality. In its extreme form this notion requires that an improvisation be done once and never heard in any form again. Solomon's insistence that a recorded improvisation, "upon replay, is no longer an improvisation" (226) reduces experienced immediacy on the part of both listeners and improvisers to an infinitely small now, a Euclidean point, excluding both the past and the future.

However, listeners have heard some recorded improvisations literally thousands of times. The performances are learned by heart, yet even after many years, new layers of meaning are spontaneously discovered. While 
a memorized improvisation is, taken note by note, utterly predictable, these recorded versions often seem to renew themselves when viewed in a more expansive temporal context. Moreover, improvisers are hearing their music at the same time as any potential listener; in this sense, the experiences of improviser and listener are similar. Returning to Walton's identification of the role of empathy in listening to improvisations, it seems clear that the listener also improvises, posing alternative paths, experiencing immediacy as part of the listening experience.

The elimination of memory and history from music, emblematic of the Cageian project, may be seen as a response to postwar conditions. Seen in historical terms, the decline of improvisation in European music in the nineteenth and early twentieth centuries would seem to preclude any identification of exclusively or even primarily European antecedents for Eurological improvised music. In such an atmosphere, the postwar modernist emphasis of musicians such as Cage on "the present," deemphasizing memory and history, would appear to be a natural response to the impossibility of discovering such antecedents on the part of those for whom the preservation of European purity of musical reference would be a prime concern.

This response to historical conditions, moreover, may be viewed not only in terms of the more usually theorized postwar modernist desire to be made new through "negation of the principles of the previous tradition" (Born 1995, 40) but, again, with respect to the quintessentially American myth of the frontier, where that which lies before us must take precedence over "the past." On the other hand, the African-American improviser, coming from a legacy of slavery and oppression, cannot countenance the erasure of history. The destruction of family and lineage, the rewriting of history and memory in the image of whiteness, is one of the facts with which all people of color must live. It is unsurprising, therefore, that from an ex-slave's point of view an insistence on being free from memory might be regarded with some suspicion-as either a form of denial or of disinformation.

\section{Improvised Music}

The classically trained pianist Mildred Portney Chase has written of the value of improvisation for composers, performers, and students of music-particularly children. For performers of notated music-for whom "most of the music we study comes from another time and place" (Chase 1988, 95)-improvisation can provide "moments of inspiration similar to those experienced by the greatest composers - even if the comparison ends there" (93). Alternatively, improvisation can aid in helping 
a composer to open "channels of his musical stream of consciousness ... being utterly permissive, he may open at the deepest levels those passages to the musical persona that are buried underneath all that he consciously knows" (90).

For Chase, although she questions the historical composer-performer axis typical of Eurological music, her book-in chapters titled "To the Composer," "To the Pianist," and so on-frames improvisation as something done by performers and composers-not exactly a combination of the two, but something similar. This framework does not seem to leave room for the musical role of "improviser"; indeed, there is no chapter titled "To the Improviser."

In fact, a field termed "improvised music" has arisen and come to some prominence in the period since 1970. I would identify improvised music as a social location inhabited by a considerable number of present-day musicians, coming from diverse cultural backgrounds and musical practices, who have chosen to make improvisation a central part of their musical discourse. Individual improvisers are now able to reference an intercultural establishment of techniques, styles, aesthetic attitudes, antecedents, and networks of cultural and social practice.

Media reports, scholarly essays, and other literature about such musicians have tended to coalesce around "improvised music," a posteriori, as a catch-all term for a variety of musical forms. Bailey (1992) has written perhaps the most perceptive essays on the topic of what improvised music is - to him - and how it has evolved.

Working as an improviser in the field of improvised music emphasizes not only form and technique but individual life choices as well as cultural, ethnic, and personal location. In performances of improvised music, the possibility of internalizing alternative value systems is implicit from the start. The focus of musical discourse suddenly shifts from the individual, autonomous creator to the collective-the individual as a part of global humanity.

In order to distinguish improvised music as a field from Eurological work "incorporating" or "using" improvisation, or featuring "indeterminacy" or aleatoric practices, the simplistically racialized taxonomies found in texts such as the Nyman and Cope works must be abandoned. A more nuanced view of improvised music might identify as more salient differentiating characteristics its welcoming of agency, social necessity, personality, and difference, as well as its strong relationship to popular and folk cultures.

In my own view, the development of the improviser in improvised music is regarded as encompassing not only the formation of individual musical personality but the harmonization of one's musical personality 
with social environments, both actual and possible. This emphasis on personal narrative is a clear sign of the strong influence of the Afrological on improvised music.

One important model in the area of improvised music is the sort of "open" improvisation practiced by members of the Association for the Advancement of Creative Musicians (AACM), the African-American musicians' collective widely recognized for the variety of innovative musical ideas promulgated by its membership since its inception in 1965 on Chicago's nearly all-black South Side. Along with the important St. Louis-based Black Artists Group, including improvisers such as saxophonists Hamiet Bluiett, Oliver Lake, and Julius Hemphill, the AACM improvisers were clearly Afrological in perspective as a group, yet influenced individually by a wide range of non-Afrological musics.

The AACM's improviser-composers include pianist Muhal Richard Abrams (a founding member of the organization); saxophonist Fred Anderson; multi-instrumentalist Douglas Ewart; the Art Ensemble of Chicago; saxophonists Anthony Braxton, Henry Threadgill, and Edward Wilkerson; drummer Kahil El-Zabar; pianist Amina Claudine Myers; violinist Leroy Jenkins; trumpeter Wadada Leo Smith; and the trombonist-author. Other frequent collaborators have included the pianist Anthony Davis, saxophonist David Murray, and flutist James Newton.

The "AACM model" stresses a composer-improviser orientation and the importance of asserting the agency, identity, and survival of the African-American artist: "The Black creative artists must survive and persevere in spite of the oppressive forces which prevent Black people from reaching the goals attained by other Americans. We must continue to add copiously to an already vast reservoir of artistic richness handed down through the ages. Black artists must control and be paid for what they produce, as well as own and control the means of distribution" (Abrams and Jackson 1973, 72).

Another important and very different model of "improvised music" is practiced by the European "free" improvisers, such as contrabassist Joelle Léandre; guitarist and theorist Derek Bailey; bassist Barry Guy; pianists Misha Mengelberg, Alexander von Schlippenbach, and Irene Schweizer; percussionist Paul Lytton; vocalists Maggie Nicols and Phil Minton; multi-instrumentalist and composer Lindsay Cooper; and saxophonists Peter Brötzmann and Evan Parker. Reflecting their diverse backgrounds, these musicians often blend personal narrative reminiscent of an Afrological perspective with sonic imagery characteristic of European forms spanning several centuries.

The European form places great emphasis on the social necessity for the role of improviser. Bailey $(1992,142)$ is very clear on this point: "Im- 
provisation has no need of argument and justification. It exists because it meets the creative appetite that is a natural part of being a performing musician and because it invites complete involvement, to a degree otherwise unobtainable, in the act of music-making." In this regard it becomes entirely probable that the direct use of the term "improvised music" in the sense that I am using it here began among this group of European improvisers. The term was adopted, I believe, not to distinguish it from jazz in the sense of critique but to better reflect the European improvisers' sense of having created a native model of improvisation, however influenced by Afrological forms.

Bailey, like other European improvisers, makes no attempt to deny the Afrological influence upon his own work. Bailey's critique of jazz, therefore, far from adopting the premises of Cage in critiquing its improvisers, is actually a critique of the art world surrounding jazz, with its tendency toward canonization and toward what is perceived by many as its capitulation to the influence of corporate power in the form of a rather limp neoclassicism (Bailey 1992, 48). In this sense Bailey's critique finds company in Radano's similarly pointed critique (Radano 1993, 269).

A third strain within improvised music is the so-called "downtown (New York) school," represented by saxophonist John Zorn; guitarists Fred Frith, Eugene Chadbourne, and Elliott Sharp; vocalist Shelley Hirsch; percussionists David Moss and Ikue Mori; trombonist Jim Staley; harpist Zeena Parkins; and electronic improviser Bob Ostertag, among others. The music of this group is often timbrally and dynamically disjunctive, with rapid and frequent changes of mood and extremes of dynamics, extensive use of timbres reminiscent of rock, and strong interface with popular culture. Again, the emphasis here on personality in improvisation is Afrological in nature; this group, in my view, has attempted to come to terms with the innovations of Cage in terms of time, spontaneity, and memory, while declining to accept Cage's critique of jazz and improvisation.

Perhaps the most thorough accounts of the AACM's early activity are contained in Radano (1992; 1993). Jost (1975), Litweiler (1984), Wilmer (1992), and Corbett (1994) also contain useful and informative accounts. Litweiler (1984), Bailey (1992), Dean (1992), and Corbett (1994) contain a good deal of information on European post-free jazz improvisers. The East German critic Bert Noglik $(1981 ; 1990)$ has written extensively on these musicians as well, although these German-language works are difficult to locate. As for information on the "downtown" school, this group is much better documented on recordings than in print at the present time; the accompanying discography of improvised music should prove 
useful. In any event, this brief survey of certain areas within improvised music can hardly be taken as exhaustive.

The extensive and well-documented collaborations among improvisers from these and other cultural locations lead us to a view of improvised music, seen in historical terms, as a transcultural practice. For example, California's large and vibrant Asian-American improvisers' community-which includes pianists Jon Jang and Glenn Horiuchi; saxophonists Russel Baba, Gerald Oshita, and Francis Wong; bassist Mark Izu; storyteller Brenda Wong Aoki; and kotoist Miya Masaoka-has made a point of exploring and researching the musical, cultural, and political links between Afro-American, Euro-American, and Asian-American musical forms (see Jang 1985-88; Houn 1985-88).

In recent years, moreover, the emergence of musicians who do not claim roots in either European or American forms has further served to identify improvised music's transcultural nature. Improvisers such as the Korean percussionist $\mathrm{Kim} \mathrm{Jin} \mathrm{Hi}$, the Japanese multi-instrumentalist Torikai Ushio, and the South African percussionist Thebe Lipere have become part of the increasing internationalization of improvised music. Their examples emphasize the dangers of essentialist thinking with regard to the connection between music, race, and national origin. The recent biography of the South African pianist Chris McGregor (McGregor 1995 ) is a useful guide to some of these transnational and transcultural issues.

Given the above-mentioned historical antecedents and the associated and concomitant social and cultural themes, we can now identify "improviser" as a functional musical activity role in world musical society, along with such roles as "composer," "performer," "interpreter," "psychoacoustician," and various flavors of "theorist." In identifying the role of "improviser," the derived notion of improvisation as "real-time composition" is implicitly disavowed. Once this construct is discarded, the notion of the improviser as "performer" in the Eurological sense also comes into question, since in many cases, the piece that the improviser is to "perform" is missing.

I do not, however, wish to present these musical activity roles as fixed constructions but as potentials. Creating compositions for improvisers (again, rather than a work which "incorporates" improvisation) is part of many an improviser's personal direction. The work of Roscoe Mitchell, Anthony Braxton, John Zorn, and Misja Mengelberg provide examples of work that retains formal coherence while allowing aspects of the composition to interact with the extended interpretation that improvisers must do-thus reaffirming a role for the personality of the improviser-performers within the work. 


\section{Freedom}

The advent of various strains of "free" improvisation-including "free" jazz, which emerged in the early 1960s, as well as the European "free" improvisation which emerged in several cultural strata in the 1970s-placed "freedom" back on the musical agenda. In the case of "free" jazz, the tumultuous push for human rights in the United States had clear analogues in the music, as remarked upon by politically active musicians such as Archie Shepp. With regard to the improvisations of musicians such as Vinko Globokar and Cornelius Cardew, where improvisation itself became a symbol for freedom, the events of May 1968 in Paris and other European capitals could be seen as germane ${ }^{4}$ (Globokar 1979, 29-30).

As with the theme of spontaneity, notions of freedom and control differ markedly between Eurological and Afrological viewpoints. "Free jazz" was, as one can readily observe from the drummer Arthur Taylor's interviews with Afrological improvisers (Taylor 1993), quite controversial among jazz musicians. Whatever the viewpoints of the musicians on free jazz itself, the responses of several improvisers on the topic of "freedom" are instructive. In particular, the Eurological discourse concerning "rules" for improvisation is almost entirely absent. Rather, the improvisers seem to agree that freedom in Afrological improvisation is perceived as being possible only through discipline, defined as technical knowledge of music theory and of one's instrument as well as thorough attention to the background, history, and culture of one's music.

Drummer Elvin Jones puts the case succinctly with regard to his own involvement in what some people called "freedom music": "There's no such thing as freedom without some kind of control, at least self-control or self-discipline.... Coltrane did a lot of experimenting in that direction ... even though it gave an impression of freedom, it was basically a well thought out and highly disciplined piece of work" (quoted in Taylor 1993, 228). The bassist Ron Carter, on the same subject, maintains that "you can

4. In 1968, a number of European cities experienced student and worker strikes, riots, and other disturbances. These events proved to have a trenchancy of effect and affect that was at first severely underestimated, both by traditonal governmental authority and by the European intellectual establishment of the day.

In analyzing the causes of this new militancy, both commentators and participants agreed that the unrest could be viewed as a revolt against various forms of societal repression. The more conservative, technocratically oriented J. J. Servan-Schreiber $(1969,21)$ ascribed the citizen activism to "the confrontation of a particularly rigid social order with an accelerating technological, scientific-and therefore intellectual-transformation."

Perhaps more in tune with the aesthetic and cultural currents of the period, the famous French leader of the May 1968 Nanterre student strikes, Daniel "Danny the Red" Cohn-Bendit, attributed the power of the movement to "an 'uncontrollable' spontaneity" (Bourges 1968, 103). 
play as free as you want, only you should have some kind of background to relate to this freedom. Otherwise you're putting yourself into a corner" (quoted in Taylor 1993, 61).

Another view constructs freedom as always being present through improvisation. The drummer Philly Joe Jones insists that improvisation is itself perfectly free and not in need of any license: "Everybody's been playing free. Every time you play a solo you're free to play what you want to play. That's freedom right there" (quoted in Taylor 1993, 48). Echoing this theme, pianist Randy Weston says of "free music," "I don't see how this music is more free than another. I've heard Monk take one note and create unbelievable freedom. Freedom is a natural development" (quoted in Taylor 1993, 27).

Among improvisers from the Eurological standpoint, freedom is sometimes framed in terms of European music's traditional composer-to-performer hierarchy. According to Chase (1988, 15), "improvisation is the free zone in music, where anything is permitted and considered acceptable. You are responsible only to yourself and to the dictates of your taste." Similarly, preparation for improvisation is described in terms of the need to "free ourselves from those negative attitudes that inhibit us."

A much more widespread view that has evolved in Eurological music circles with regard to improvisation is the notion that, to be musically coherent, improvisation cannot be left as "free," but must instead be "controlled" or "structured" in some way. The composer and critic Tom Johnson's characterization of Cage's indeterminacy is typical: "Cage began referring to work indeterminate of its performance because to have called his work 'improvisations' would have implied that the performers were not guided by goals and rules" (Johnson 1989, 207-208). Another reason for asserting this necessity for rules is exemplified in the complaint by Berio $(1985,81)$ that "improvisation presents a problem in that there's no true unanimity of discourse among the participants, only, once in a while, a unity of behavior."

In any event, the most common Eurological method of providing these rules is the construction, by a composer, of autonomous, often culturally ad hoc systems of specified musical behavior options. These systems typically leave certain dimensions intentionally unspecified and presumably available for filling in as desired. Diether De la Motte has outlined a number of rule-specification strategies used by 1960s and 1970s European composers into whose works improvisation has been "included" ("einbezogen"). De la Motte includes his own comments and critiques about the procedures used. For example, Bernd Alois Zimmermann's Tempus Loquendi (1963) for flute solo uses nine phrases already created by the composer. If the soloist wishes, he or she is "encouraged" ("ermuntern") 
to improvise "personal" versions from the given material (De la Motte 1979, 45).

Sometimes the rules concern not what to play, but what to think. Stockhausen's description of his "intuitive" music, as exemplified by his composition "Aus den sieben Tagen," rejects any notion that his "intuitive music" might be regarded as a pseudonym for improvisation. His justification for distancing his "intuitive" work from improvisation resurrects a version of the motif theory: "One always connects improvisations with the presentation of underlying schemata, formulae, and stylistic elements"5 (Stockhausen 1971, 123). For Stockhausen, music should come directly from the intuition, manifesting a unity of mood, which he describes in a play on words of the meanings of "einstimmen" (to agree) and "Stimmung" (tuning or mood):

The orientation of the musicians, which I have also called "Einstimmung" [unanimity of mood/tuning], is, however, not an arbitrary or purely negative one-excluding all musical thought in certain directions-rather, it is at any given time concentrated through a text written by me, which provokes the intuition in a completely definite fashion. ${ }^{6}$ (Stockhausen 1971, 123-124; translation mine)

Even a simple set of these ad hoc formalisms, however, would still require a certain amount of preparation for their performance-presumably reducing their capacity for inducing spontaneity or provoking intuition. Moreover, despite the apparent attempt by many Eurological commentators to differentiate these performer choice systems from Afrological improvisative systems, the systems described by De la Motte in particular often seem reminiscent of the African-American practice of using chord progressions, appropriately named "changes," as musical behavior options systems. Though the Eurological "choice" systems do not necessarily present harmonic sequences, they nonetheless function in analogous ways in promoting, guiding, and conditioning real-time choice, thereby producing "changes" in the content of the music.

In any event, performer choice and "intuition" systems, as promulgated by Stockhausen and other Eurological composers, do indeed turn out to be somewhat different from improvisation in the Afrological sense. These systems seem to take account of the absence of pedagogy in the Eurological music education system with regard to improvisation. At the

5. Da man mit Improvisation immer auch die Vorstellung von zugrunde liegenden Schemata, Formeln, stilistischen Elementen verbindet.

6. Die 'Orientierung' der Musiker, die ich auch 'Einstimmung' nannte, ist aber nicht eine beliebige oder nur negative-das heißt, alles musikalische Denken in bestimmten Richtungen ausschließende-, sondern sie ist jeweils konzentriert durch einen von mir geschriebenen Text, der das Intuitive in ganz bestimmter Weise herausfordert. 
very least, they are designed to compensate for this lack by mitigating, for the performer, the "terrifying prospect of being free to play whatever comes to mind" (Small 1987, 302), by providing material to supplement or even to supplant the performer's own creative lexicon.

My own view is that in analyzing improvisative musical activity or behavior in structural terms, questions relating to how, when, and why are critical. On the other hand, the question of whether structure exists in an improvisation - or for that matter, in any human activity-often begs the question in a manner that risks becoming not so much exegetic as pejorative. It should be axiomatic that, both in our musical and in our human, everyday-life improvisations, we interact with our environment, navigating through time, place, and situation, both creating and discovering form. On the face of it, this interactive, form-giving process appears to take root and flower freely, in many kinds of music, both with and without preexisting rules and regulations.

\section{Personality}

One important aspect of Afrological improvisation is the notion of the importance of personal narrative, of "telling your own story." Berliner's subchapter on this topic identifies this metaphor of the story as underlying the structural process of many improvisers (Berliner 1994, 201). Erroll Garner encapsulates this viewpoint well: "If you take up an instrument, I don't care how much you love somebody, how much you would like to pattern yourself after them, you should still give yourself a chance to find out what you've got and let that out" (quoted in Taylor 1993, 97).

Part of telling your own story is developing your own "sound." An Afrological notion of an improviser's "sound" may be seen as analogous to the Eurological concept of compositional "style," especially in a musically semiotic sense. Moreover, for an improviser working in Afrological forms, "sound," sensibility, personality, and intelligence cannot be separated from an improviser's phenomenal (as distinct from formal) definition of music. Notions of personhood are transmitted via sounds, and sounds become signs for deeper levels of meaning beyond pitches and intervals. The saxophonist Yusef Lateef $(1985-88,44)$ makes it plain: "The sound of the improvisation seems to tell us what kind of person is improvising. We feel that we can hear character or personality in the way the musician improvises."

Crucial to the creation of a personal sound is the development of analytic skill on the part of an improviser. For the beginner, this process almost always commences with the emulation of other improvisers. Fraser $(1983,141)$ quotes Gillespie to the effect that an improviser starts by 
"playing exactly like somebody else." Such emulation amounts to a version of music analysis for music based in orature and the body. Fraser further maintains that "the prospective improviser ... is enculturated into a way of listening and of regarding the environment. ... A way of hearing develops, a preferred musical language, the terms and patterns of which one subconsciously employs to listen to the world" (81).

Interestingly, Cage's critique of jazz also likens it to personal storytelling. Cage's description of jazz seems to liken the music to a ring shout: "The form of jazz suggests too frequently that people are talking-that is, in succession-like in a panel discussion. ... If I am going to listen to a speech then I would like to hear some words" (quoted in Zwerin 1991, 162). This perceptive comment from a composer who could not, by any stretch of the imagination, be portrayed as possessing any affinity with Afrological musical forms, provides some intersubjective justification for the notion that one of the central aesthetic demands made on Afrological improvisers is that the improviser "tell a story."

In any event, Eurological improvisers have tended to look askance on the admission of personal narrative into improvisative activity. I believe that, for postwar Eurological improvisers, the ideas of Cage have, again, had the greatest impact in this regard: "What I would like to find is an improvisation that is not descriptive of the performer, but is descriptive of what happens, and which is characterized by an absence of intention" (quoted in Kostelanetz 1987, 222). Interviewing the members of AMM, the composer Christopher Hobbs states that one of the joys of listening to the group is that "you can't distinguish who is playing what, and that it is completely unimportant one way or the other" (Childs and Hobbs 1982-83, 40). British composer Gavin Bryars, who moved away from improvisation during the 1970s, maintained that "one of the main reasons I am against improvisation now is that in any improvising position the person creating the music is identified with the music. ... It's like standing a painter next to his picture so that every time you see the painting you see the painter as well and you can't see it without him" (quoted in Bailey 1992, 115).

In some respects the distancing of personal narrative updates the concept of a post-Kantian "autonomous significant structure" identified by Subotnik in her essays on contemporary Eurological music. This autonomy is based on the assumption that "humans can build structures or domains that are complete and meaningful within themselves." Moreover, according to Subotnik $(1991,266)$, "the recognition of validity in such a structure is not thought to depend on the particular identity, power, habits, or values of those who create or receive the structure in question. 
Rather, validity is supposed to inhere in the ability of a structure to carry out its own laws with consistency."

Subotnik believes that this ideal of autonomy is a fiction; the popular understanding of Gödel's theorem concerning the impossibility of a logical system's self-description in its own terms would seem to provide some corroboration. In any event, Bryars's painterless painting, as well as the Cageian notion of "sounds as themselves"-possessing only frequency, loudness, length, overtone structure, morphology (Cage 1961, 14), divorced from social or cultural implications-would seem to harmonize well with this concept of autonomy.

As with the motif theory of improvisation, even in Eurological music the notion of personal narrative and autonomy has been the subject of debate. Though the members of the innovative improvisation group Musica Elettronica Viva (including pianist Alvin Curran, electronic improviser Richard Teitelbaum, trombonist Garrett List, and pianist Frederic Rzewski) have all had close associations with Cage, their ideas about group improvisation-as with other "post-Cage improvisers" such as Malcolm Goldstein - seem to part company with Cage's views. Frederic Rzewski's "Description and Analysis of a Process" maintains that the music of MEV is "based on friendship. This element of friendship is communicated in the music; it cannot be concealed" (Rzewski 1968, 3).

Earlier in this passionate, brilliant, yet somewhat rambling treatise, Rzewski states that "Any unfriendly act on the part of some individual threatens the strength of the music we are all trying to create" (3). Malcolm Goldstein $(1988,10)$ is even more direct than Rzewski, maintaining, with Erroll Garner, that the improvisative act demands from the improviser that an answer be created to this important question: "Who are you? How do you think or feel about this moment/sounding?" Perhaps the most trenchant conception of what improvisation can be is to be found in this testament by Charlie Parker: "Music is your own experience, your thoughts, your wisdom. If you don't live it, it won't come out of your horn" (quoted in Levin and Wilson 1994, 24). The clear implication is that what you do live does come out of your horn.

My sincere thanks go to Bonnie Wright of Spruce Street Forum in San Diego; to Prof. Jann Pasler, my colleague at UCSD; and to Muhal Richard Abrams, all of whom made useful suggestions about the text. Thanks are also due to Isabelle Lytton, for information on the German critic Bert Noglik. 


\section{A SELECTED DISCOGRAPHY OF IMPROVISED MUSIC}

Abrams, Muhal Richard, and Roscoe Mitchell. Duets and solos. Black Saint 120133-2. Compact disc.

Anderson, Fred, and Steve McCall. Vintage duets. Okkadisk OD12001. Compact disc.

Art Ensemble of Chicago. A jackson in your house. Affinity CD AFF752. Compact disc.

Bailey, Derek. Solo guitar, volume 2. Incus CD11. Compact disc.

Braxton, Anthony, and Evan Parker. Duo (London) 1993. Leo LR 193. Compact disc.

Brötzmann, Peter, and Hamid Drake. The dried rat-dog. Okkadisk OD12004. Compact disc.

Chadbourne, Eugene. Strings. Intakt CD 025. Compact disc.

Curran, Alvin, and the ROVA Saxophone Quartet. Electric rags II. New Albion NA027. Compact disc.

Davis, Anthony. The ghost factory. Gramavision 18-8807-2. Compact disc.

Ethnic Heritage Ensemble. Dance with the ancestors. Chameleon 61494-2. Compact disc.

Ewart, Douglas. Bamboo meditations at Banff. Arawak AA003. Compact disc.

Goldstein, Malcolm. Sounding the new violin. Nonsequitur/What Next? WN0005. Compact disc.

Guy, Barry, and the London Jazz Composers Orchestra. Theoria. Intakt CD 024. Compact disc.

Hemphill, Julius. Big band. Elektra/Musician 9-60831-2. Compact disc.

Hirsch, Shelley, and David Weinstein. Haiku lingo. Review Records 139. Compact disc.

Horiuchi, Glenn. Calling is it and now. Soul Note 121268-2. Compact disc.

Izu, Mark. Circle of fire. Asian Improv Records AIR 0009. Compact disc.

Jang, Jon, and the Pan-Asian Arkestra. Self defense! Soul Note 121203-2. Compact disc.

Jenkins, Leroy, and Muhal Richard Abrams. Lifelong ambitions. Black Saint 120033-2. Compact disc.

Lacy, Steve. Futurities. Hat ART 6031/6032. Two compact discs.

Leandre, Joelle, and Carlos Zingaro. Écritures. ADDA 590038. Compact disc.

Lewis, George. Changing with the times. New World 80434-2. Compact disc.

Masaoka, Miya. Compositions. Asian Improv Records AIR 0010. Compact disc.

Mengelberg, Misha. The ICP Orchestra performs Monk. ICP 026. Compact disc.

Mitchell, Roscoe. Roscoe Mitchell Quartet. Sackville 2009.

Myers, Amina Claudine. Salutes Bessie Smith. Leo LR 103. Compact disc.

Newton, James. Suite for Frida Kahlo. AudioQuest Musics AQ-CD1023. Compact disc.

Ostertag, Bob. Attention span. RecDec 33. Compact disc.

Parker, Evan. 50th anniversary concert. Leo LR 212/213. Compact disc.

Schweizer, Irene. Piano solo, volume 1. Intakt CD 020. Compact disc.

Smith, Wadada Leo. Kulture jazz. ECM 1507. Compact disc.

Spontaneous Music Ensemble. Karyobin. Chronoscope CPE2001-2. Compact disc.

Staley, Jim. Don Giovanni. Einstein 002. Compact disc.

Teitelbaum, Richard. Concerto grosso. Hat ART CD 6004. Compact disc.

Threadgill, Henry. Making a move. Columbia CK67214. Compact disc.

Wong, Francis. Ming. Asian Improv Records AIR 0009. Compact disc.

Zorn, John. Cobra. Hat Hut CD 60401/60402. Two compact discs. 


\section{REFERENCES}

Abrams, Muhal Richard, and John Shenoy Jackson. 1973. Association for the Advancement of Creative Musicians. Black World 23, no. 1 (November):72-74.

Bailey, Derek. 1992. Improvisation: Its nature and practice in music. London: British Library National Sound Archive.

Becker, Howard. 1982. Art worlds. Berkeley: University of California Press.

Berio, Luciano. 1985. Two interviews. London: Marion Boyars.

Berliner, Paul F. 1994. Thinking in jazz. Chicago: University of Chicago Press.

Born, Georgina. 1995. Rationalizing culture. Berkeley: University of California Press.

Bourges, Hervé. 1968. The student revolt: The activists speak. Translated by B. R. Brewster. London: Jonathan Cape.

Braxton, Anthony. 1985. Tri-Axium writings, volume 1. Dartmouth: Synthesis/Frog Peak.

Cage, John. 1961. Silence: Lectures and writings. Middletown, Conn.: Wesleyan University Press.

Chase, Mildred Portney. 1988. Improvisation: Music from the inside out. Berkeley: Creative Arts.

Childs, Barney, and Christopher Hobbs, eds. 1982-83. Forum: Improvisation. Perspectives of New Music 21:26-112.

Cope, David. 1993. New directions in music. Madison: Brown and Benchmark.

Corbett, John. 1994. Extended play: Sounding off from John Cage to Dr. Funkenstein. Durham: Duke University Press.

Dahlhaus, Carl. 1979. Was heisst Improvisation? In Improvisation und neue Musik: Acht Kongreßreferate, edited by Reinhold Brinkmann, 9-23. Mainz: Schott.

Dean, Roger T. 1992. New structures in jazz and improvised music since 1960. Philadelphia: Open University Press.

De la Motte, Diether. 1979. Improvisation in der neuen Musik. In Improvisation und neue Musik: Acht Kongreßreferate, edited by Reinhold Brinkmann, 42-54. Mainz: Schott.

Fiske, John. 1994. Media matters: Everyday culture and political change. Minneapolis: University of Minnesota Press.

Fraser, Wilmot A. 1983. Jazzology: A study of the tradition in which jazz musicians learn to improvise. Ph.D. diss., University of Pennsylvania.

Globokar, Vinko. 1979. Reflexionen über Improvisation. In Improvisation und neue Musik: Acht Kongreßreferate, edited by Reinhold Brinkmann, 24-41. Mainz: Schott.

Goldstein, Malcolm. 1988. Sounding the full circle. Sheffield, England: Goldstein/Frog Peak.

Gridley, Mark. 1994. Jazz styles: History and analysis. Englewood Cliffs, N.J.: Prentice-Hall.

Harris, Cheryl I. 1993. Whiteness as property. Harvard Law Review 106, no. 8:1707-1791.

Houn, Fred Wei-han. 1985-88. Asian American music and empowerment. Views on Black American Music 3:27-32.

Jang, Jon. 1985-88. We don't all sound alike. Views on Black American Music 3:33-38.

Johnson, Tom. 1989. The voice of new music: New York City 1972-1982. Eindhoven, Netherlands: Het Apollohuis.

Johnson-Laird, Philip N. 1991. Jazz improvisation-A theory at the computational level. In Representing musical structure, edited by Peter Howell, Robert West, and Ian Cross, 291-325. London: Academic Press.

Jones, LeRoi. 1963. Blues people. New York: William Morrow.

Jost, Ekkehard. 1975. Free jazz. Vienna: Universal Edition.

Kofsky, Frank. 1970. Black nationalism and the revolution in music. New York: Pathfinder.

Kostelanetz, Richard. 1987. Conversing with Cage. New York: Limelight.

Lateef, Yusef A. 1985-88. The pleasures of voice in improvised music. Views on Black American Music 3:43-47. 
Levin, Michael, and John S. Wilson. 1994. No bop roots in jazz: Parker. Down Beat 61, no. 2:24-25. (Originally published September 9, 1949.)

Lipsitz, George. 1995. The possessive investment in whiteness: Racialized social democracy and the "White" problem in American studies. American Quarterly 47, no. 3:369-427.

Litweiler, John. 1984. The freedom principle: Jazz after 1958. New York: Da Capo Press.

Mandeles, Chad. 1981. Jackson Pollock and jazz: Structural parallels. Arts Magazine 57:139-141.

McGregor, Maxine. 1995. Chris McGregor and the Brotherhood of Breath: My life with a South African jazz pioneer. Flint, Mich.: Bamberger Books.

Noglik, Bert. 1981. Jazz-werkstatt international Musik. Berlin: Verlag Neue Musik.

_. 1990. Wege improvisierter Musik. Berlin: Verlag Neue Musik.

Nyman, Michael. 1974. Experimental music: Cage and beyond. New York: Schirmer Books.

Radano, Ronald. M. 1992. Jazzin' the classics: The AACM's challenge to mainstream aesthetics. Black Music Research Journal 12, no. 1:79-95.

- 1993. New musical figurations: Anthony Braxton's cultural critique. Chicago: University of Chicago Press.

Revill, David. 1992. The roaring silence: John Cage, a life. New York: Arcade Publishing.

Rzewski, Frederic. 1968. Description and analysis of a process. Unpublished, obtained from the author.

Schwartz, Elliott, and Daniel Godfrey. 1993. Music since 1945: Issues, materials and literature. New York: Schirmer.

Servan-Schreiber, J. J. 1969. The spirit of May. New York: McGraw-Hill.

Sloboda, John A. 1985. The musical mind: The cognitive psychology of music. Oxford: Oxford University Press.

Small, Christopher. 1987. Music of the common tongue. London: Calder.

Solomon, Larry. 1985. Improvisation II. Perspectives of New Music 24, no. 2:224-235.

Somers, Margaret R., and Gloria D. Gibson. 1994. Reclaiming the epistemological "Other": Narrative and the social constitution of identity. In Social theory and the politics of identity, edited by Craig Calhoun, 37-99. Cambridge: Blackwell.

Stockhausen, Karlheinz. 1971. Texte zur Musik 1963-1970. Köln: Verlag M. DuMont Schauberg.

Subotnik, Rose Rosengard. 1991. Developing variations: Style and identity in Western music. Minneapolis: University of Minnesota Press.

Taylor, Arthur. 1993. Notes and tones: Musician-to-musician interviews. Leige, Belgium: A Taylor, 1977. Reprint, New York: Da Capo Press.

Walton, Ortiz. 1972. Music: Black, white and blue. New York: William Morrow.

Wilmer, Valerie. 1992. As serious as your life: The story of the new jazz. London: Allison and Busby, 1977. Reprint, London: Serpent's Tail.

Zwerin, Michael. 1991. A lethal measurement. In John Cage: An anthology, edited by Richard Kostelanetz, 161-168. New York: Praeger, 1970. Reprint, New York: Da Capo Press. 